DE DE GRUYTER

OPEN

G

DOI: 10.1515/genst -2015-0012

\title{
BEAUTY AND THE BEAST FROM A COGNITIVE LINGUISTIC PERSPECTIVE: ANIMAL METAPHORS FOR WOMEN IN SERBIAN AND ROMANIAN
}

\author{
ANNAMARIA KILYENI \\ Politehnica University Timişoara \\ 2, Victoriei Sq, 300006 Timişoara, Romania \\ annamaria.kilyeni@upt.ro \\ NADEŽDA SILAŠKI \\ University of Belgrade, Serbia \\ 6, Kamenička St., Belgrade, Serbia \\ silaskin@sbb.rs
}

\begin{abstract}
Under the theoretical wing of Conceptual Metaphor Theory, we present a contrastive cognitive and linguistic analysis of the WOMEN ARE ANIMALS metaphor as used in Romanian and Serbian. Our main aim is to establish whether the names of the same animals are used in the two languages to conceptualise women and their various characteristics (particularly physical appearance and character traits), or alternatively, whether the two languages exhibit any linguistic or conceptual differences in this regard.
\end{abstract}

Keywords: animal metaphor, Conceptual Metaphor Theory, Romanian, Serbian, women. 


\section{Introduction}

The focus of this paper is on the contrastive cognitive-linguistic analysis of the WOMEN ARE ANIMALS metaphor as used in Serbian and Romanian. In particular, the main purpose of our research was to establish whether or not, and if so the extent to which, the two cultures use the names of the same animals to metaphorically conceptualise women in positive or negative terms. In addition, we were interested in the contribution of the gender factor to cultural variation in the use of animal metaphors referring to women.

As explained in section 3, data collection was carried out using the same (except for two minor differences) purposely designed questionnaire, which we administered to male and female respondents in both countries in the official language of each country, Serbian and Romanian respectively. It is worth mentioning that the results for Serbian are also presented separately and in more detail in Silaški (2013).

The findings of our small-scale study are given in section 4, where they are also discussed in terms of productivity as well as in that of conceptual and linguistic variation, according to gender and culture (including value judgment).

\section{Theoretical framework}

Our study draws on Conceptual Metaphor Theory (CMT), a framework of analysis established by Lakoff and Johnson (1980). If metaphor was traditionally regarded as a figure of speech used to add rhetorical flourishes, CMT has demonstrated that it is deeply embedded in our way of conceptualizing the world and that therefore metaphors realized in language, i.e. "metaphorical linguistic expressions" (Kövecses 2002:4), are 
only possible due to the underlying conceptual metaphors that structure our thinking. According to CMT, metaphor represents a central cognitive process that allows us to perform a set of cross-domain mappings between two conceptual domains: the (usually) more abstract target domain and the more easily comprehensible source domain. In short, metaphors reflect our conceptual structure - they occur in speech because our mind is metaphorical in nature, and, consequently, researching what we say may help us to establish what we actually think.

If we turn our attention to animal metaphors, they can be formulated in cognitive linguistic terms as PEOPLE ARE ANIMALS and HUMAN BEHAVIOUR IS ANIMAL BEHAVIOUR (cf. Kövecses 2002). Given that "[m]uch of human behavior seems to be metaphorically understood in terms of animal behavior" (Kövecses 2002:124), "the domain of animals is an extremely productive source domain" (Kövecses 2002:17), and as a result, animal metaphors are commonly used in many languages to describe people (e.g. Halupka-Rešetar \& Radić 2003, Prodanović-Stankić 2004, Talebinejad \& Dastjerdi 2005, Hsieh 2006, Kövecses 2006, Wang \& Dowker 2008, Silaški \& Đurović 2010, Silaški 2013). The metaphorical application of animal names to people seems to be intrinsically linked to the process of anthropomorphization on the one hand, and to metonymy on the other, since only those humanly attributed characteristics which are typical of an animal and which stand for that animal are metaphorically projected onto people (cf. Kövecses 2002:124-125, Talebinejad \& Dastjerdi 2005:145).

Moreover, as emphasized by López Rodríguez (2009:94), “[a]nimal metaphors not only have a cognitive basis, but are also culturally motivated, that is, they reflect the attitudes and beliefs held by a particular community towards certain animal species, and, therefore, may vary from culture to 
culture, in time and space." Such metaphors are used as one of the tools of constructing social identity, in general, and gender identity, in particular, and "are crucial in understanding the ideologies, the kinds of discourses we employ when we deal with the subject matter of women and men" (Kovecses 2006:152). Also, given their role in semantic derogation (cf. Fontecha \&Catalán 2003), animal metaphors can be classified as gender metaphors, that is, "ideological metaphors in which the conceptual mapping(s) that is (are) projected from the source to the target domain may create and/or reflect some kind of discrimination against men or women" (VelascoSacristan 2009:142).

Consequently, analyses of culture-specific animal metaphors such as the present one may result in our gaining an important insight into a dominant cultural model of a particular society.

\section{Method and materials}

In order to achieve our goal, we designed a questionnaire which we administered to 30 male and 30 female students at the University of Belgrade, Serbia and at the Politehnica University of Timișoara, Romania, all of them aged between 21 and 23. Initially, both the questionnaire in Serbian and that in Romanian contained the same 20 animal names which we, as native speakers, intuitively thought were used to refer to women and which we therefore chose deliberately (the name of each animal is first given in Serbian and then in Romanian, together with the English equivalent); thirteen were names of domestic animals (mačka/pisică 'cat', patka/rață 'duck', svinja/porc 'pig', krmača/scroafă 'sow', kokoška/găină 'hen', koza/capră 'she-goat', kuja/cățea 'bitch', ovca/oaie 'sheep', kobila/iapă 'mare', krava/vacă 'cow', guska/gâscă 'goose', ćurka/curcă 
'turkey', mazga/măgăriță 'jenny'), whereas seven were names of wild animals (lisica/vulpe 'fox', riba/pește 'fish', tigrica/tigroaică 'tigress', zmija/șarpe 'snake', slonica/elefant '(she-) elephant', žirafa/girafă 'giraffe', lavica/leoaică 'lioness'). The questionnaire in Romanian, however, underwent a minor change, in that one more animal name (balenă 'whale'), which was expected to be very productive in Romanian, was added prior to administration. This was not possible for the Serbian version, as the questionnaire had already been filled in by the respondents; in addition, there was no point in including whale in the Serbian questionnaire, since this particular animal metaphor is not productive in Serbian for the purpose of referring to women.

Another difference between the two questionnaires lies in the gender of the nouns designating animals. Although we had intended to use only feminine nouns for the chosen animals, this was not possible in Romanian (please note that "feminine" and "masculine" here refer to grammatical gender, which is characteristic of both Serbian and Romanian and which may not always coincide with natural gender). While all the Serbian nouns in our questionnaire denoting animals are feminine, both grammatically and biologically (with three generic names: lisica 'fox', riba 'fish' and žirafa 'giraffe'), three of the Romanian animal nouns are masculine: porc 'pig', pește 'fish' and elefant 'elephant'. We should observe that the last of these is a generic word, i.e. it may designate both the male and the female of the species, despite its being grammatically masculine (exceptionally); there is no different form for distinguishing she-elephants. The first two are also generic words but they do have different feminine designations for the female animals: scroafă 'sow' was included in the questionnaire as it was believed to have slightly different connotations from the generic, 
grammatically masculine porc 'pig', whereas peștoaică - the noun for a female fish - was intentionally ignored, as it is hardly ever used in speech. This was also the case with vulpoaică 'vixen'; the generic, also grammatically feminine vulpe 'fox' was preferred instead.

The questionnaires were anonymous, but all the respondents had to specify their gender and age. They were then asked: (1) to circle the names of those animals which they would use to refer to a woman, and (2) to give the characteristics (physical and/or mental) of a female person that they would refer to by using the selected animal names (the students were encouraged to use adjectives rather than write lengthy explanations).

Furthermore, it should be noted that both diminutive and hypocoristic forms were excluded from our analysis despite their major role in the semantic derogation of women in the animal realm (cf. López Rodríguez 2007), but these will definitely be the focus of a future study.

In what follows, we will present the results of our study and discuss the most relevant ones in terms of linguistic and conceptual variation as well as of productivity between the two sexes, on the one hand, and between the two languages, on the other.

\section{Results and discussion}

The table below shows what animal names, in what percentage, as well as whether in a positive, negative or neutral way, were used by Serbian and Romanian male and female respondents to refer to a woman. The name of each animal is first given in English, its equivalent in Serbian and Romanian being provided in the second column. Due to space constraints, abbreviations have been used for the two languages under discussion, namely SR and RO respectively. 


\begin{tabular}{|c|c|c|c|c|c|c|c|c|c|}
\hline \multirow{2}{*}{\multicolumn{2}{|c|}{ ANIMAL NAME }} & \multicolumn{2}{|c|}{$\begin{array}{c}\% \text { female } \\
\text { respondents }\end{array}$} & \multicolumn{2}{|c|}{$\begin{array}{l}\text { Evaluation by } \\
\text { female } \\
\text { respondents }\end{array}$} & \multicolumn{2}{|c|}{$\begin{array}{c}\% \text { male } \\
\text { respondents }\end{array}$} & \multicolumn{2}{|c|}{$\begin{array}{l}\text { Evaluation by } \\
\text { male } \\
\text { respondents }\end{array}$} \\
\hline & & SR & RO & SR & RO & SR & RO & SR & RO \\
\hline \multirow{2}{*}{ 1. CAT } & mačkasR & \multirow{2}{*}{$68 \%$} & \multirow{2}{*}{$80 \%$} & \multirow{2}{*}{$+/-$} & \multirow{2}{*}{$+/-$} & \multirow{2}{*}{$90 \%$} & \multirow{2}{*}{$87 \%$} & \multirow{2}{*}{$+/-$} & \multirow{2}{*}{$+/-$} \\
\hline & pisicăRO & & & & & & & & \\
\hline \multirow{2}{*}{ 2. DUCK } & patkasR & \multirow{2}{*}{$3 \%$} & \multirow{2}{*}{$43 \%$} & \multirow{2}{*}{-} & \multirow{2}{*}{-} & \multirow{2}{*}{$3 \%$} & \multirow{2}{*}{$33 \%$} & \multirow{2}{*}{-} & \multirow{2}{*}{ - } \\
\hline & rațăRO & & & & & & & & \\
\hline \multirow{2}{*}{ 3. PIG } & svinjasR & \multirow{2}{*}{$29 \%$} & \multirow{2}{*}{$0 \%$} & \multirow{2}{*}{ - } & \multirow{2}{*}{ / } & 120 & 70 & & \\
\hline & porc $\mathrm{RO}$ & & & & & & & & \\
\hline & krmačasR & 260 & $73 \%$ & 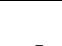 & 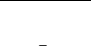 & 470 & 770 & 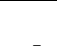 & 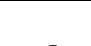 \\
\hline 4. SUw & scroafăRO & 年 & 年 & & 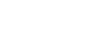 & 年 & 年 & & \\
\hline & kokoškasR & $48 \%$ & $30 \%$ & - & 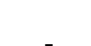 & $67 \%$ & $270 \%$ & 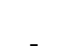 & - \\
\hline J. HEIV & găinăRO & & & & & & 2170 & & \\
\hline & kozasR & & & & & & & & \\
\hline 6. SHE GOAT & caprăRO & 1070 & & 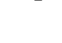 & 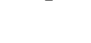 & 2570 & 5010 & 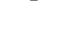 & 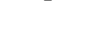 \\
\hline & kujasR & 30 & $80 \%$ & 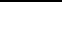 & 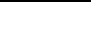 & $20 \%$ & 770 & 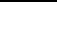 & 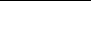 \\
\hline 1.ВНСН & cățeaRo & & 年 & & 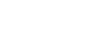 & 2070 & 列 & 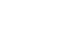 & \\
\hline & ovcasR & 260 & $170 /$ & & lnout & 270 & $10 \%$ & & Inout \\
\hline 8. SHEЕР & oaiero & 2070 & 178 & - & - & 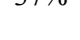 & 1070 & 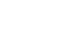 & thitur. \\
\hline & kobilasR & & & & & & & & \\
\hline 9. MARE & iарӑRO & 1070 & 2570 & 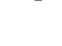 & - & 070 & 5070 & 1 & - \\
\hline & kravasR & $300 \%$ & $70 \%$ & 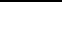 & 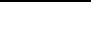 & $30 \%$ & $77^{\circ} \%$ & 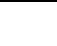 & 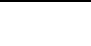 \\
\hline $10.00 \mathrm{w}$ & vacăRO & & & & & & & & \\
\hline & lisicasR & $55 \%$ & $73 \%$ & +1 & +1 & $50 \%$ & 670 & +1 & +1 \\
\hline 11. FOX & vulpe $_{\text {RO }}$ & 格 & 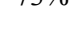 & 年 & 年 & 8070 & 0170 & . & $17=$ \\
\hline & ribasR & $55 \%$ & $10 \%$ & $+1-$ & -lneut & $70 \%$ & $3 \%$ & + & - \\
\hline 12. ГIDH & peștero & & & . & 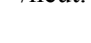 & 年 & 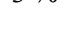 & . & \\
\hline & tigricasR & $19 \%$ & $43 \%$ & $+1-$ & $+/-$ & $37 \%$ & $77 \%$ & + & $+/-$ \\
\hline 13. 1IUKESS & tigroaicăRO & 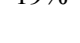 & 年 & . & 年 & 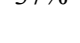 & 年 & $r$ & 西 \\
\hline & guskasR & $10 \%$ & $270 /$ & 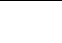 & 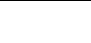 & $10 \%$ & 270 & 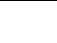 & \\
\hline 14. GUOSE & gâscăRO & $17 \%$ & 2170 & 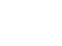 & 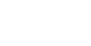 & (70) & 2170 & 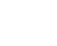 & 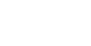 \\
\hline & zmijasR & $77^{\circ} \%$ & $17 \%$ & - & & $60 \%$ & $37 \%$ & & \\
\hline 15. STARL & şarpero & & & & & & & & \\
\hline 16. TURKEY & ćurkasR & $39 \%$ & $50 \%$ & - & - & $53 \%$ & $23 \%$ & - & - \\
\hline
\end{tabular}




\begin{tabular}{|c|c|c|c|c|c|c|c|c|c|}
\hline & curcăRO & & & & & & & & \\
\hline \multirow{2}{*}{ 17. ELEPHANT } & slonicasR & \multirow{2}{*}{$3 \%$} & \multirow{2}{*}{$20 \%$} & \multirow{2}{*}{ - } & \multirow{2}{*}{ - } & \multirow{2}{*}{$0 \%$} & \multirow{2}{*}{$10 \%$} & \multirow{2}{*}{ / } & \multirow{2}{*}{ - } \\
\hline & elefant $t_{R O}$ & & & & & & & & \\
\hline \multirow{2}{*}{ 18. JENNY } & mazgasR & \multirow{2}{*}{$26 \%$} & \multirow{2}{*}{$40 \%$} & \multirow{2}{*}{ - } & \multirow{2}{*}{ - } & \multirow{2}{*}{$7 \%$} & \multirow{2}{*}{$37 \%$} & \multirow{2}{*}{-} & \multirow{2}{*}{ - } \\
\hline & măgărițăRo & & & & & & & & \\
\hline \multirow[b]{2}{*}{ 19. GIRAFFE } & žirafasR & \multirow{2}{*}{$26 \%$} & \multirow{2}{*}{$83 \%$} & \multirow{2}{*}{ neut. } & \multirow{2}{*}{-/neut. } & \multirow{2}{*}{$20 \%$} & \multirow{2}{*}{$47 \%$} & \multirow{2}{*}{ neut } & \multirow{2}{*}{-/neut. } \\
\hline & girafãRo & & & & & & & & \\
\hline \multirow{2}{*}{ 20. LIONESS } & lavicasR & \multirow{2}{*}{$64 \%$} & \multirow{2}{*}{$77 \%$} & \multirow{2}{*}{$+/-$} & \multirow{2}{*}{$+/-$} & \multirow{2}{*}{$57 \%$} & \multirow{2}{*}{$50 \%$} & \multirow{2}{*}{+} & \multirow{2}{*}{+} \\
\hline & leoaicăRO & & & & & & & & \\
\hline \multirow[b]{2}{*}{ 21. WHALE } & balenăRO & & \multirow[b]{2}{*}{$80 \%$} & & \multirow[b]{2}{*}{ - } & & & & \\
\hline & & & & & & & $73 \%$ & & - \\
\hline
\end{tabular}

The results given in the table show that, as far as the extent of usage of animal names is concerned, both Serbian female respondents and Romanian male respondents would use the names of all the listed animals to refer to a woman. Similarly, Romanian female respondents would use the names of all the listed animals except 'pig', which male respondents would use to refer to women who are fat, unattractive, dirty and sloppy. Serbian male respondents, on the other hand, would use all the listed names except two: 'mare' and 'she-elephant'. Both of these animal names which Serbian men would never use to refer to a woman are used by female respondents to refer to a woman's physical appearance, namely fatness and obesity. In addition, the results indicate that 'cat' is by far the most productive animal source concept in both languages, irrespective of gender of user, with an average of $81 \%$. 'Bitch' is almost equally productive in Romanian only, with an average comparable to that for 'whale' (78.5\% and $76.5 \%$, respectively), while in Serbian it is among the least frequent (11.5\%), together with 'mare' (6.5\%), 'duck' (3\%) and 'elephant' (1.5\%). Another notable difference between the two cultures lies in the extent to which Serbian and Romanian respondents, in general, and Serbian and Romanian 
male respondents, in particular, would use the word 'fish': an impressive $70 \%$ versus a mere $3 \%$.

As for the endowment of animal metaphors with a positive or negative evaluation, our findings reveal that neither Serbian nor Romanian female respondents would use any of the animal names to refer only positively to a woman. Animal names that Serbian men would definitely use to refer to a woman in solely positive terms are the following: 'fish', 'tigress' and 'lioness', which, interestingly enough, are all names of wild animals. By contrast, Romanian men would only use 'lioness' in a solely positive way. The first two of these animal names, 'fish' and 'tigress', are exclusively related to a woman's physical appearance, namely good looks, as illustrated by a number of adjectives Serbian male respondents gave when asked to provide physical and/or mental characteristics of women which they would refer to by using a particular animal name (e.g. attractive, pretty, sexy, seductive), whereas 'tigress' is additionally used to refer to the way a woman behaves during sexual intercourse (e.g. lustful, passionate). 'Lioness' was selected by male respondents in both cultures as the term which would be employed to refer to a strong, ambitious, persistent, selfconfident, self-sacrificing and protective woman, devoted to her family, with the observation that many Romanian male respondents also perceive a 'lioness' as a physically attractive, sexy woman. Except for Serbian male students and respectively, both Serbian and Romanian male students, the other respondents also gave a negative evaluation to 'tigress' and 'lioness', associating these animal names with women who are dangerous, conceited, aggressive and domineering.

As far as negative animal metaphors are concerned, more than $60 \%$ of the animal names would be used in an exclusively negative manner by 
respondents from both countries. It is interesting to note that, in Serbian, the same animal names were evaluated negatively by both female and male respondents, except for 'mare' and 'she-elephant', which none of the male students circled in the questionnaire. Likewise, the same animal names were given negative connotations by the Romanian male and female students, with the exception of 'pig', which got $0 \%$ from the female respondents, and of 'mare' and 'fish', which were perceived as neutral by several male and in the latter case female respondents.

The top five negatively evaluated animal names according to female respondents were the following:

$>$ in Serbian: 'snake' (77\%), 'hen' and 'she-goat' (48\%), 'turkey' and 'cow' (39\%);

$>$ in Romanian: 'bitch' and 'whale' (80\%), 'sow' (73\%), 'cow' (70\%) and 'turkey' (50\%).

Compare the top five negative animal metaphors according to male respondents:

$>$ in Serbian: 'hen' (67\%), 'snake' (60\%), ‘turkey' (53\%), 'sow' (47\%) and 'goose' (40\%);

$>$ in Romanian: 'cow' (77\%), 'bitch' (77\%), 'sow' (77\%), 'whale' (73\%), 'snake' and 'jenny' (37\%).

If we take a closer look at the male choices, we observe that, despite the difference in percentage use, 'sow' would be used by both Serbian and Romanian male students to refer mainly to two apparently highly undesirable and unpopular attributes of women in the eyes of men - obesity and untidiness - as demonstrated by the most commonly provided adjectives fat and sloppy. Similarly, 'whale' seems to be an extremely productive animal metaphor among Romanian men (but also women), 
usually employed to describe very fat, obese women, and more rarely, stupid women. Males' answers generally suggest that a 'snake' is a woman who is cunning, shrewd, dangerous, malicious, mean, deceitful, astute, egotistic, selfish, self-centred, two-faced and greedy. A woman who is garrulous or chatty is referred to by men as a 'hen' in both Serbian and Romanian, but also as a 'turkey' or a 'goose' in Romanian only. In addition, the name 'turkey' is apparently used in Serbian to describe gullible, credulous women, while these negative qualities are associated with a 'hen' and a 'goose' in the minds of Romanian male respondents. Additionally, 'hen', 'turkey' and 'goose' are used by Serbian males to metaphorically describe stupid, unintelligent women, whereas such women are referred to by Romanian men only as a 'hen' or a 'goose'. According to our survey, stupid women as well as fat women are perceived as 'cows' in both languages, but this term additionally suggests crassness and clumsiness in women in Romanian. Both Serbian and Romanian male respondents think of an unfaithful woman or one who engages in promiscuous sex as a 'bitch', while the latter respondents also added the following recurrent adjectives to the list for this term: mean, impudent, annoying (which were also chosen to describe a 'jenny'), and materialistic.

As far as animal metaphors evaluated both positively and negatively are concerned, our analysis points to very similar results for the two languages. For instance, 'cat' imparts an extremely positive evaluation, as expected, and would most often be used to refer to women who are attractive, seductive, pretty, gentle and elegant. Surprisingly, however, respondents also used a fairly wide array of negative-connotation adjectives, such as dangerous, calculated, and self-indulgent, but also double-faced, sly, narcissistic and cold in Romanian only. Similarly, a woman described 
as a 'fox' is simultaneously clever, shrewd, intelligent, seductive, provocative, beautiful, funny, sexy, and hot, but also sly, cunning, doublefaced and scheming.

The results presented in the table also show that negative and neutral evaluation of the same animal name is present in Romanian only, with one exception. The only animal name which would be used in a neutral manner by Serbian men and women and which is apparently void of any evaluative stance (at least when discussed in a decontextualised manner) is 'giraffe'. This particular animal metaphor is used to refer to a tall woman, without conveying any specific, evaluation either positive or negative. This partially holds true for Romanian, where this name commonly has an additional negative stance, pointing not only to extremely tall women, but also to conceited and stupid women, according to a few respondents. 'Fish' is another animal name that is evaluated in both a negative and a neutral manner by Romanian female respondents only, as inferred from the adjectives slippery and self-centred, on the one hand, and silent, on the other.

To summarise, our small-scale analysis has thrown up some interesting findings. Firstly, the two languages, Serbian and Romanian, seem to exhibit little variation in terms of endowment of animal metaphors with positive / negative evaluation. The most significant difference lies in the use of the noun 'fish', which is typically positive in Serbian but negative in Romanian. It is noteworthy that the vast majority of Serbian and Romanian animal names are used by both male and female respondents to convey negative evaluations, with far fewer being used to denote positive characteristics of women; this parallels the findings of Talebinejad \& Dastjerdi (2005), who state that "most, but certainly not all, animal-related 
metaphors capture the negative characteristics of human beings" (Talebinejad \& Dastjerdi 2005:137). The results also suggest that large farmyard animals ('cow', 'sow', 'pig', 'goat', 'sheep') usually imply fatness, ugliness, untidiness and stupidity, while farm birds ('turkey', 'hen', 'goose', 'duck') usually connote stupidity, naivety, carelessness, ignorance, indifference and clumsiness in both cultures. Similarly, wild animals (e.g. 'lioness', 'tigress') are generally used to refer to sexually active, physically attractive and powerful women. Another interesting observation is that there is little difference in the positive / negative evaluation of animal metaphors between female and male respondents in either country.

In terms of productivity, the figures indicate that the use of animal metaphors generally seems to be more pronounced among Romanian respondents. However, apart from a few major differences in productivity between the two cultures at the level of individual animal names, as presented at the beginning of this section, the overall percentages are fairly balanced. Also, we can say that a few animal metaphors seem to be used significantly more frequently by the female respondents in one country, as compared to male respondents in the same country, and vice versa.

Finally and somewhat unexpectedly, the results of the study suggest that women are inclined to be more critical than men towards other women. As we have already pointed out earlier in this section, none of the female respondents would use any of the listed animal names to refer to women solely in positive terms. What is more, this phenomenon seems to be more apparent in Romania, where the number of female respondents who would use animal names pejoratively to refer to a woman is a little higher than that of male respondents who would do so. 


\section{Conclusion}

From the results of our small-scale study of the use of animal names to refer to women in Serbian and in Romanian, we may conclude that, despite the few cases of cultural or percentage variation emphasized above, the majority of the animal metaphors analysed are generally used disparagingly, with negative behavioural and / or sexual connotations, and hence reveal the sexism entrenched in the two languages under discussion. Moreover, it appears that there is no substantial difference between men and women when it comes to the extent of the usage of such metaphors in Serbian and in Romanian; both male and female respondents displayed a substantially discriminatory view of women, according to which women are viewed and treated as less than human beings. In other words, irrespective of whether they come from Serbia or from Romania, both "Beauty" and "the Beast" seem to be guilty of "linguistic discrimination" (Fontecha \& Catalan 2003:772). By using more or less the same negatively connoted metaphorical expressions from the animal realm and sharing the tendency towards degrading women, they both contribute equally to maintaining and perpetuating gender-specific ideologies. It should be pointed out, however, that the findings derived from our small-scale study should be taken as tentative and that more comprehensive and thorough studies are needed if we are to arrive at firm conclusions which may then be generalized.

\section{Acknowledgement}

The paper is the result of research conducted within project no. 178002 Languages and cultures across time and space funded by the Ministry of Education, Science and Technological Development of the Republic of Serbia. 


\section{References}

Fontecha, A.F. and R.M.J. Catalán. 2003. "Semantic Derogation in Animal Metaphor: A Contrastive-Cognitive Analysis of Two Male/Female Examples in English and Spanish”. Journal of Pragmatics 35:771-797.

Halupka-Rešetar, S. and B. Radić. 2003. "Animal Names Used in Addressing People in Serbian”. Journal of Pragmatics 35:1891-1902.

Hsieh, S. C. 2006. "A Corpus-Based Study on Animal Expressions in Mandarin Chinese and German”. Journal of Pragmatics 38: 2206-2222.

Kövecses, Z. 2002. Metaphor. A practical introduction. Oxford: Oxford University Press.

Kövecses, Z. 2006. "Metaphor and Ideology in Slang: The Case of WOMAN and MAN". Revue d'Études Françaises 11/2006:152-166.

Lakoff, G. and M. Johnson. 1980. Metaphors We Live By. Chicago: University of Chicago Press.

López Rodríguez, I. 2007. “The Representation of Women in Teenage and Women's Magazines: Recurring Metaphors in English”. Estudios Ingleses de la Universidad Complutense 15:15-42.

López Rodríguez, I. 2009. “Of Women, Bitches, Chickens and Vixens: Animal Metaphors for Women in English and Spanish”. Cultura, Lenguaje y Representación / Culture, Language and Representation VII/2009:77-100.

Nilsen, A.P. 1996. "Of Lady Bugs and Billy Goats: What Animal Species Names Tell about Human Perceptions of Gender". Metaphor and Symbolic Activity 11:257271.

Prodanović-Stankić, D. 2004. "Metafore s nazivima životinja u engleskom i srpskom jeziku”. Zbornik Matice srpske za filologiju i lingvistiku XLVII (1-2):131-145.

Silaški, N. 2011. “Animal Metaphors in Some Business-Related Terms in English”. Radovi Filozofskog fakulteta u Istočnom Sarajevu13(1):565-576.

Silaški, N. 2013. "Animal Metaphors and Semantic Derogation - Do Women Think Differently from Men?”. Gender Studies 12/2013:319-332.

Silaški, N. and T. Đurović. 2010. "Catching Inflation by the Tail - Animal Metaphoric Imagery in the Conceptualisation of INFLATION in English". Ibérica 20:57-80.

Talebinejad, M. R. and H. V. Dastjerdi. 2005. "A Cross-Cultural Study of Animal Metaphors: When Owls Are Not Wise!", Metaphor and Symbol 20(2):133-150. 
Velasco-Sacristan, M. 2009. “Overtness-Covertness in Advertising Gender Metaphors”. Journal of English Studies 7/2009:111-148.

Wang, C. and A. Dowker. 2008. "Interpretation of Animal Metaphors: Evidence from Chinese and English Children and Adults". Proceedings of the Child Language Seminar 2007, University of Reading, 2008:226-235. 